\title{
Isolated metastasis to the foot as an extremely rare presenting feature of primary endometrial cancer. Case report and review of the literature
}

Leszek Gottwald ${ }^{1-3}$, Andrzej Dukowicz ${ }^{2}$, Janusz Piekarski ${ }^{4}$, Grazyna Pasz-Walczak ${ }^{5}$, Michal Spych ${ }^{6,7}$, Sylwia Kazmierczak-Lukaszewicz ${ }^{1,2}$, Aleksandra Cialkowska-Rysz ${ }^{1,2}$

1Palliative Care Unit, Chair of Oncology, Medical University of Lodz, Poland 2Department of Palliative Medicine, Regional Cancer Centre, Copernicus Memorial Hospital of Lodz, Poland

${ }^{3}$ Gynaecological Cancer Outpatient Clinic, Regional Cancer Centre, Copernicus Memorial Hospital of Lodz, Poland

4Department of Surgical Oncology, Chair of Oncology, Medical University of Lodz, Poland

${ }^{5}$ Department of Pathology, Chair of Oncology, Medical University of Lodz, Poland 6Department of Radiotherapy, Chair of Oncology, Medical University of Lodz, Poland ${ }^{7}$ Department of Teleradiotherapy, Regional Cancer Centre, Copernicus Memorial Hospital of Lodz, Poland

Submitted: 13 May 2010

Accepted: 6 September 2010

Arch Med Sci 2012; 8, 1: 172-174

DOI: 10.5114/aoms.2012.27299

Copyright (C 2012 Termedia \& Banach

Endometrial cancer is the most common invasive cancer of the female genital tract, with an increasing incidence rate. Abnormal uterine bleeding is the presenting symptom in $75-90 \%$ of cases $[1,2]$. The majority of patients with endometrial cancer are diagnosed with no evidence of extrauterine spread (70-80\% stage I), which gives patients better prognosis $[1,3]$. In more advanced disease the sites commonly affected outside the uterus are pelvic and para-aortic lymph nodes and the ovaries [4]. Similarly to uterine sarcomas, distant metastases in advanced or recurrent endometrial cancer most commonly involve the lungs, liver, central nervous system and skin [4-6].

Metastases to bones have been described in $2-15 \%$ of patients with metastatic disease, and the most common site of osseous metastases are vertebrae, with pelvic bones, ribs and sternum [3, 7]. Isolated metastases to bone extremities are extremely rare, and thought to result from the haematological spread of cancer cells [5]. The review of the Medline database by searching the items endometrial cancer and metastases to extremities showed twenty such cases, with only nine cases when metastatic tumour of the foot was the first manifestation of endometrial cancer (Table I) [3, 5, 7-13].

A 74-year-old female suffered from pain and swelling of the right foot from October 2006. In the X-ray picture and bone scintigraphy, suspected lesion of the right calcaneus, talus and metatarsal bones was detected (Figure 1). Afterwards it was histologically verified in the biopsy as metastatic cancer (Figure 2). The patient had no vaginal bleeding or other gynaecological symptoms, but subsequent computed tomography scans showed an enlarged uterus. Uterine curettage confirmed the diagnosis of endometrial cancer. The patient was treated with total abdominal hysterectomy, bilateral salpingo-oophorectomy without pelvic lymph node dissection in December 2006. The histological diagnosis was a moderate differentiated (G2) endometrioid endometrial cancer

\author{
Corresponding author: \\ Leszek Gottwald MD, PhD \\ Palliative Care Unit \\ Chair of Oncology \\ Medical University of Lodz \\ 2 Ciolkowskiego \\ 93-509 Lodz, Poland \\ Phone: +48 426895481 \\ Fax: +48 426895482 \\ E-mail: lgottwald@wp.pl
}


invading the outer half of the myometrium $(>1 / 2)$ with invasion of cervical stroma. The fallopian tubes and the ovaries showed no signs of metastases. No evidence of macroscopic abdominopelvic metastases was found at surgery. Her disease was classified as clinical stage IVB according to FIGO 2009 staging, but in the TNM classification it was PT2 Nx M2.
In January 2007 the patient was admitted to the department of palliative radiotherapy. She received irradiation by Co 60 until a total dose of 20 Gy to the tumour of the right foot, with complete resolution of symptoms. The patient was discharged from hospital in March 2007. During the observation from surgery in December 2006 until June 2010 no other metastases were detected. The patient remains alive

Table I. Isolated metastasis to the bones of the extremities as the first manifestation of endometrial cancer - review of the literature

\begin{tabular}{|c|c|c|c|c|c|c|c|}
\hline $\begin{array}{l}\text { Author/year } \\
\text { (references) }\end{array}$ & $\begin{array}{c}\text { Age } \\
\text { [years] }\end{array}$ & Histology & Grade & $\begin{array}{c}\text { Bone } \\
\text { involved }\end{array}$ & $\begin{array}{c}\text { Other } \\
\text { metastasis }\end{array}$ & Treatment & $\begin{array}{l}\text { Survival } \\
\text { [months] }\end{array}$ \\
\hline $\begin{array}{l}\text { Vanecko RM, } \\
\text { et al./1967 [10] }\end{array}$ & 54 & - & - & Fibula & - & - & - \\
\hline Onuba O/1983 [13] & 57 & $\begin{array}{c}\text { Endometrioid } \\
\text { adenocarcinoma }\end{array}$ & - & Tibia & $\begin{array}{l}\text { Lung, } \\
\text { kidney }\end{array}$ & - & - \\
\hline $\begin{array}{l}\text { Cooper JK, } \\
\text { et al./1994 [7] }\end{array}$ & 59 & $\begin{array}{c}\text { Endometrioid } \\
\text { adenocarcinoma }\end{array}$ & 2 & Calcaneus & No & $\begin{array}{c}\text { Chemotherapy, } \\
\text { radiotherapy }\end{array}$ & $>60$ \\
\hline $\begin{array}{l}\text { Petru E, } \\
\text { et al./1995 [11] }\end{array}$ & 61 & $\begin{array}{c}\text { Endometrioid } \\
\text { adenocarcinoma }\end{array}$ & 1 & Tarsus & No & $\begin{array}{l}\text { Chemotherapy, } \\
\text { hormone therapy }\end{array}$ & 10 \\
\hline $\begin{array}{l}\text { Malicky ES, } \\
\text { et al./1997 [12] }\end{array}$ & 44 & $\begin{array}{c}\text { Endometrioid } \\
\text { adenocarcinoma }\end{array}$ & 2 & Femur & No & $\begin{array}{c}\text { Radiotherapy, } \\
\text { hormone therapy }\end{array}$ & $>12$ \\
\hline $\begin{array}{l}\text { Manolitsas TP, } \\
\text { et al./2002 [3] }\end{array}$ & 76 & $\begin{array}{c}\text { Endometrioid } \\
\text { adenocarcinoma }\end{array}$ & 3 & Calcaneus & No & Radiotherapy & 20 \\
\hline $\begin{array}{l}\text { Uharcek P, } \\
\text { et al./2006 [8] }\end{array}$ & 67 & $\begin{array}{c}\text { Endometrioid } \\
\text { adenocarcinoma }\end{array}$ & 1 & $\begin{array}{c}\text { Calcaneus, talus } \\
\text { and metatarsal } \\
\text { bones }\end{array}$ & No & $\begin{array}{c}\text { Surgery, } \\
\text { chemotherapy, } \\
\text { hormone therapy }\end{array}$ & $>20$ \\
\hline $\begin{array}{l}\text { Loizzi V, } \\
\text { et al. } 2006 \text { [5] }\end{array}$ & 73 & $\begin{array}{c}\text { Endometrioid } \\
\text { adenocarcinoma }\end{array}$ & 3 & Tibia & No & Chemotherapy & 9 \\
\hline $\begin{array}{l}\text { Kaya A, } \\
\text { et al./2007 [9] }\end{array}$ & 70 & $\begin{array}{c}\text { Endometrioid } \\
\text { adenocarcinoma }\end{array}$ & 1 & Tibia & No & Radiotherapy & $>47$ \\
\hline This case, 2010 & 74 & $\begin{array}{c}\text { Endometrioid } \\
\text { adenocarcinoma }\end{array}$ & 2 & $\begin{array}{c}\text { Calcaneus, talus } \\
\text { and metatarsal } \\
\text { bones }\end{array}$ & No & Radiotherapy & $>40$ \\
\hline
\end{tabular}
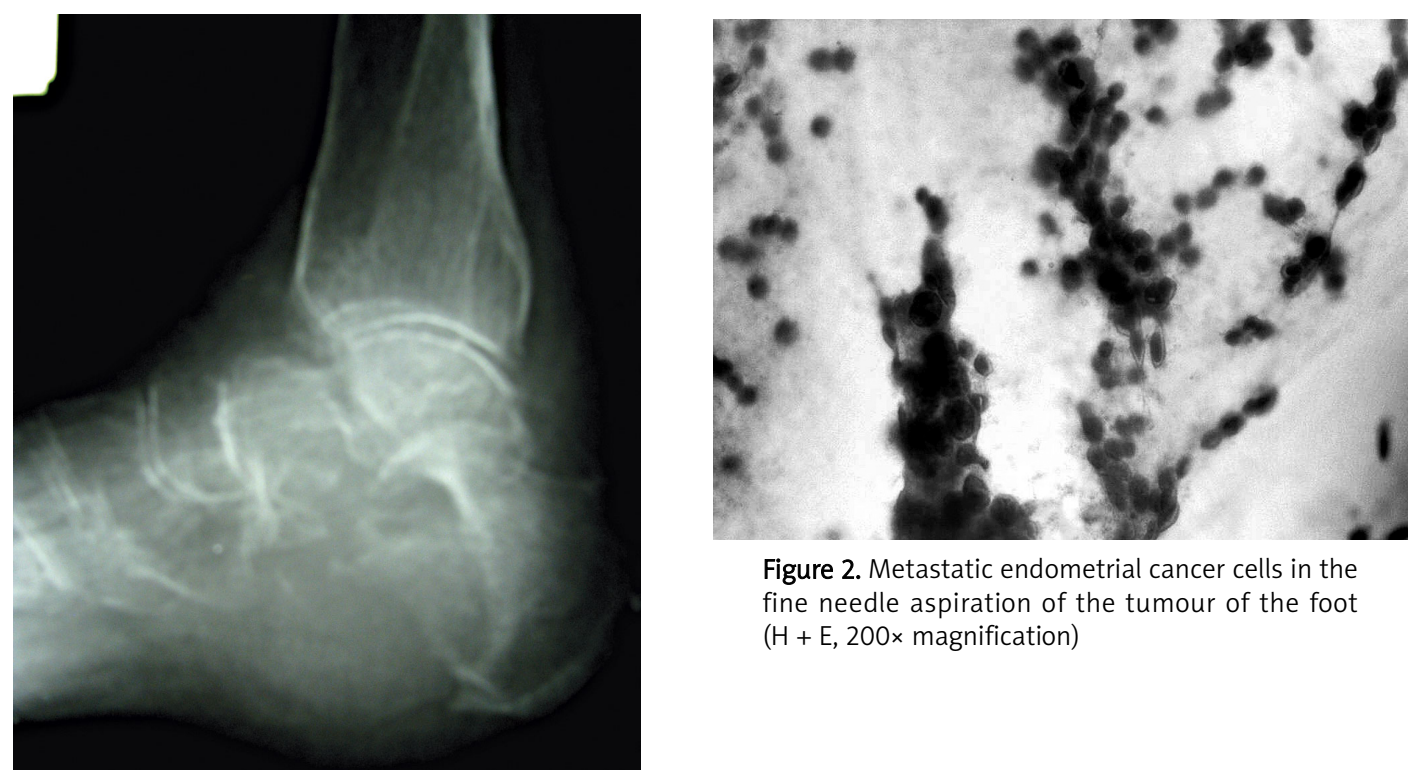

Figure 2. Metastatic endometrial cancer cells in the fine needle aspiration of the tumour of the foot $(H+E, 200 \times$ magnification)

Figure 1. Radiograph of the right foot demonstrating metastases of the endometrial cancer 
and asymptomatic 43 months after the diagnosis of metastatic endometrial cancer to the foot.

Our report presented in the previous section has three main peculiar features: 1) it demonstrates endometrial cancer that presented with osseous metastasis, which is a rare occurrence, 2 ) the metastatic tumour was located in the foot, which is extremely rare, 3 ) the bone lesion was a single bone metastasis, which is unusual in such cases. Additionally, the case in which isolated metastatic tumour of the extremity was the first manifestation of endometrial cancer is the tenth such case reported in the literature (Table I), and the second one located in the calcaneus and involving talus and metatarsal bones [8].

Despite the rarity of metastases to the upper and lower extremities, there is a need to have a high index of suspicion for metastasis in patients with a history of endometrial cancer who present with swelling or bony tenderness. The initial diagnosis can be challenging, as the symptoms of pain and swelling are often attributed to other more common benign conditions such as soft tissue inflammation, trauma, arthritis, and osteomyelitis [7]. It is important to consider bone metastasis as a possible diagnosis also in patients without history of cancer, but with osseous pain not responding to conservative treatment [5, 9-13]. Appropriate imaging may include plain $\mathrm{X}$-ray picture and radionuclide bone scans [3]. Technetium diphosphonate bone scans can be positive up to 18 months before a lesion is detectable on plain X-ray [14]. Therefore, a biopsy should be performed in patients with suspected lesions, and who demonstrate evidence of bony destruction [4].

The treatment strategy in patients with confirmed isolated metastatic lesion in the bone extremity still remains a topic of controversy, because of the few descriptions available in the literature and the different bone sites involved. For these reasons, a common suitable treatment regimen cannot be established and treatment should be tailor suited to each patient. The treatment of irradiation with or without surgery, hormone therapy and chemotherapy is reported as effective in most cases and may be curative $[4,5,7,9,11,12]$. The main goal of treatment should be to eliminate or palliate pain and prolong survival.

\section{References}

1. Bokhman JV. Two pathogenetic types of endometrial carcinoma. Gynecol Oncol 1983; 15: 10-7.

2. Seebacher V, Schmid M, Polterauer S, et al. The presence of postmenopausal bleeding as prognostic parameter in patients with endometrial cancer: a retrospective multicenter study. BMC Cancer 2009; 9: 460.

3. Manolitsas TP, Fowler JM, Gahbauer RA, Gupta N. Pain in the foot: calcaneal metastasis as the presenting feature of endometrial cancer. Obstet Gynecol 2002; 100: 1067-9.
4. Amiot RA, Wilson SE, Reznicek MJ, Webb BS. Endometrial carcinoma metastasis to the distal phalanx of the hallux: a case report. J Foot Ankle Surg 2005; 44: 462-5.

5. Loizzi V, Cormio G, Cuccovillo A, Fattizzi N, Selvaggi L. Two cases of endometrial cancer diagnosis associated with bone metastasis. Gynecol Obstet Invest 2006; 61: 49-52.

6. Karolewski K, Glinski B, Jakubowicz J, et al. Uterine sarcomas - an evaluation of treatment results and prognostic factors. Arch Med Sci 2009; 5: 215-21.

7. Cooper JK, Wong FL, Swenerton KD. Endometrial adenocarcinoma presenting as an isolated calcaneal metastasis. A rare entity with good prognosis. Cancer 1994; 73: 2779-81.

8. Uharcek P, Mlyncek M, Ravinger J. Endometrial adenocarcinoma presenting with an osseous metastasis. Gynecol Obstet Invest 2006; 61: 200-2.

9. Kaya A, Olmezoglu A, Eren CS, et al. Solitary bone metastasis in the tibia as a presenting sign of endometrial adenocarcinoma: a case report and the review of the literature. Clin Exp Metastasis 2007; 24: 87-92.

10. Vanecko RM, Yao ST, Schmitz RL. Metastasis to the fibula from endometrial carcinoma. Report of 2 cases. Obstet Gynecol 1967; 29: 803-5.

11. Petru E, Malleier M, Lax S, et al. Solitary metastasis in the tarsus preceding the diagnosis of primary endometrial cancer. A case report. Eur J Gynaecol Oncol 1995; 16: 387-91.

12. Malicky ES, Kostic KJ, Jacob JH, Allen WC. Endometrial carcinoma presenting with an isolated osseous metastasis: a case report and review of the literature. Eur J Gynaecol Oncol 1997; 18: 492-4.

13. Onuba O. Pathological fracture of the right tibia, an unusual presentation of endometrial carcinoma: a case report. Injury 1983; 14: 541-5.

14. Litton GJ, Ward JH, Abbott TM, Williams HJ Jr. Isolated calcaneal metastasis in a patient with endometrial adenocarcinoma. Cancer 1991; 67: 1979-83. 